\title{
Do Firms' Characteristics Make a Difference of the Choice of Capital Budgeting Practices? Evidence from Sri Lanka
}

\author{
Lingesiya Kengatharan \\ Department of Financial Management, University of Jaffna, Sri Lanka \\ E-mail: lingesiya@yahoo.com
}

Received: May 2, 2017 Accepted: Nov. 24, $2017 \quad$ Published: December 24, 2017

doi:10.5296/ajfa.v9i2.11161 URL: https://doi.org/10.5296/ajfa.v9i2.11161

\begin{abstract}
The aim of this study was to examine the differences of the choice of capital budgeting practices in terms of firms' characteristics of Sri Lankan companies. The primary data were garnered from 186 financial officers using self-administered questionnaires. Collected data were then analysed using independent sample t- test. The Results of the study revealed that the use of simple capital budgeting practices were mostly preferred by small sized firms and mainly managed by finance professionals with non-MBA educational qualifications and short tenure. Sophisticated and advanced capital budgeting practices were used mostly by large firms; and were mainly managed by finance professionals with master of business administration qualification and long tenure. According to the industry differences, accounting rate of return was primarily applied by non-MBA qualified financial officers and was also preferred by non-manufacturing firms. None of the other methods made any significant differences in terms of type of industry. Sophisticated capital budgeting practices were determined by the size of the capital budget, advanced capital budgeting practices were determined by both the size of the capital budget and the educational qualifications of the finance professionals. In a similar vein, simple capital budgeting practices were determined by the size of the capital budget, the educational qualifications of the financial officers, and type of industry. Overall, this study has made parametric contributions to the choice of capital budgeting practices in terms of firms' characteristics of Sri Lankan companies. The findings of the study are useful to the investment decision makers when they are appraising investment projects.
\end{abstract}

Keywords: Capital budgeting practices, firm characteristics, Sri Lankan companies 


\section{Introduction}

'Capital budgeting practices are the methods and techniques used to evaluate and select an investment project' (i.e., the decision-making role of the accounting system) (Verbeeten,2006, p.108). Capital budgeting is the application of the principle of profit maximisation to multi-period projects to pave the way for a firm's growth, survival and sustainability. Capital budgeting techniques are the best alternative for investment decision makers, to help them decide to invest a fixed amount today in exchange for an uncertain stream of future payoffs. Capital budgeting decisions have been recognized as the most important strategic decisions for an organisation to determine how much to invest in specific assets and when to invest (Verbeeten, 2006).The long-term success of a firm depends on excellent investment decisions more than any other factor (Megginson, Smart \& Lucey, 2008). The majority of firms' investment decisions involve the acquisition of fixed assets, for example, the purchase of land, plant, equipment and buildings. Firms invest hundreds of billions of dollars every year in investment projects. Capital investment decisions are thus of utmost important in determining a firm's fortunes over many years.

The ways of looking at capital budgeting practices are different from country to country, from company to company and from project to project (Akalu, 2003). This scenario places emphasis on seminal studies that capital budgeting practices are influenced by a 'country effect' (e.g., Graham \& Harvey, 2001; Hermes, Smid \& Yao, 2007). Many studies has been conducted on capital budgeting methods and practices, predominantly in: the USA (e.g., Graham \& Harvey, 2001; Ryan \& Ryan, 2002), the UK (e.g., Arnold \& Hatzopoulos, 2000), Australia (e.g., Truong, Partington \& Peat, 2008), China (e.g., Chen, 2008), Canada (e.g., Bennouna, Meredith \& Marchant, 2010), Japan (e.g., Shinoda, 2010), Sweden (e.g., Sandahl \& Sjogren, 2003), Indonesia (e.g., Leon, Isa \& Kester, 2008), Ireland (e.g., Kester \& Robbins, 2011), South Africa (e.g., Maroyi \& Poll, 2012), New Zealand (e.g., Lord, Shanahan \& Bogd, 2004), Tennessee (e.g., Sekwat, 1999), Belgium (e.g., Dardenne, 1998), Romania (e.g., Dragota et al., 2010), Nigeria (e.g., Elumilade, Asaolu \& Ologunde, 2006), Pakistan (e.g., Zubairi, 2008), Argentina (Pereiro, 2006), Italy (e.g., Cescon, 1998), Singapore (e.g., Kester \& Chong, 1998), Bahrain (e.g., Al-Ajmi,Al-Saleh \& Hussain, 2011), Cyprus (e.g., Lazaridis, 2004), Croatia (e.g., Dedi \& Orsag, 2007), Jordan (e.g., Khamees, Al-Fayoumi \& Al-Thuneibat, 2010), Taiwan (e.g., Haddad, Sterk \& Wu,2010), Nepal (e.g., Poudel et al., 2009), India (e.g., Singh, Jain \& Yadav, 2012), Hong Kong (e.g., Lam, Wang \& Lam, 2007), Kuwait (e.g., Mutairi , Tain \& Tan, 2012), Libya (e.g., Mohammed, 2013), Ghana (e.g., Tufuor \& Doku, 2013), Poland (e.g., Wnuk-Pel, 2013), Kenya (e.g., Kitili \& Nganda, 2014), Spain (e.g., Andres, Fuente \& Martin, 2015). Comparative studies have been conducted in Europe: the UK, France, Germany and the Netherlands (e.g., Brounen, de Jong \& Koedijk, 2004); in the Asia-Pacific region: Malaysia, Singapore and Hong Kong (e.g., Wong, Farragher \& Leung, 1987), Australia, Hong Kong, Indonesia, Malaysia, the Philippines and Singapore (Kester et al., 1999); between British and Dutch companies (Akalu, 2003), the Netherlands and China (Hermes et al., 2007); and in Central and Eastern Europe (CEE) including Bulgaria, Croatia, the Czech Republic, Hungary, Latvia, Lithuania, Poland, Romania, the Slovak Republic, and Slovenia (Ander,Mohanty \& Toth, 2010). All of these studies have made contributions to 
extant literature by illuminating the prevailing capital budgeting practices across many countries. But studies focusing to examine the differences of the choice of capital budgeting practices in terms of firms' characteristics are very rare. Therefore this study identified the differences of the use of capital budgeting practices in terms of firms' characteristics. Statement of the research problem can be posted as Do firms' characteristics make a difference of the choice of capital budgeting practices?

\section{Capital budgeting practices}

Capital budgeting practices help managers to select $n$ out of $N$ investment projects with the highest profits and an acceptable 'risk of ruin' (Verbeeten, 2006, p.108). All capital budgeting practices can be considered into the categories of sophisticated, advanced and naive/simple based on empirical studies (e.g., Haka, 1987; Haka, Gordon \& Pinches, 1985; Verbeeten, 2006; Wolffsen, 2012). Naive practices includes payback, the adaptation of required payback and accounting rate of return, and the advanced /net present value based, including sensitivity analysis/break-even analysis, scenario analysis, the adaptation of required return/discount rate, internal rate of return, net present value, uncertainty absorption in cash flows, modified internal rate of return and profitability index. Farragher, Kleiman and Sahu (2001) suggested that a degree of sophistication is represented by the use of discounted cash flow techniques and incorporating risk into the analysis. Sophisticated capital budgeting methods generally include Monte Carlo simulations, game theory, real option, using certainty equivalents, decision trees, CAPM analysis / $\beta$ analysis, and adjusting expected values (Verbeeten, 2006; Wolffsen, 2012).

\subsection{Firm characteristics and capital budgeting practices}

This study considers firms' demographic characteristics that are expected to account for the differences in their choice of capital budgeting practices across countries. Although firms have many characteristics, many seminal studies set out three major characteristics viz., firm size, industry differences, and the financial officer's educational qualification and experience in the field that have a strong influence on the choice of capital budgeting practices (e.g., Ho \& Pike, 1992; Trigeorgis, 1993; Rogers, 1995; Ho \& Pike, 1998; Payne, Heath \& Gale, 1999; Bowman \& Moskowitz, 2001; Graham \& Harvey, 2001; Williams \& Seaman, 2001; Farragher et al., 2001; Ryan \& Ryan, 2002; Billington, Johnson \& Triantis,2003; Brounen et al.,2004; McGrath \& Nerkar, 2004; Verbeeten, 2006; Hermes et al.,2007; Verma et al.,, 2009; Bennouna et al., 2010; Andres et al., 2015)

The size of a firm is one of the major determinants of its capital budgeting practices (e.g., Ho \& Pike, 1992; Graham \& Harvey, 2001; Farragher et al., 2001; Brounen et al.,2004; Verbeeten, 2006; Mutairi et al., 2012; Lakew \& Rao, 2014;). Research supports the notion that large firms adopt more innovative capital budgeting methods, e.g. sophisticated capital budgeting practices, to a larger extent than smaller firms (e.g., Rogers, 1995; Williams \& Seaman, 2001 ), since larger firms have the capacity and resources to use sophisticated capital budgeting practices (Ho \& Pike, 1992). Payne, Heath and Gale (1999) and Ryan and Ryan (2002) documented the fact that large firms are more inclined to use more sophisticated capital budgeting practices. This is due to the fact that larger firms have larger projects and 
the use of sophisticated capital budgeting practices becomes less costly (Payne et al., 1999; Hermes et al., 2007). Many studies considered firm size as size of the capital budget in order to focus the impact of firm characteristics on the choice of capital budgeting practices (e.g.,Pike,1986; Ryan \& Ryan, 2002). Nonetheless, the nature of the relationship between the size of a firm and its capital budgeting practice has not been clearly established in literature relating to developing countries. Thus, this leads to research question:

$\mathrm{RQ}_{1}$ : Is there any significant difference between the size of a firm's capital budget and its use of capital budgeting practices?

And thus, it can be hypothesised that:

$\mathrm{H}_{1}$ : Simple capital budgeting practices are used when a firm's capital budget is small.

Companies from different industries may vary in their use of capital budgeting practices (e.g., Ho \& Pike, 1998). This may, for example, be due to the nature of their business activity, differences in technology, competition and human resource skill, the amount of investment in fixed assets, business risk, and so forth. For instance, widespread use of real option and game theory is more prevalent in the pharmaceutical industry (e.g., Bowman \& Moskowitz, 2001; McGrath \& Nerkar, 2004), the extraction industry (e.g., Trigeorgis, 1993), the financial services industry and the high-tech industry (e.g., Billington et al.,2003, Verbeeten, 2006). This scholarship explores how industrial types are different in their use of capital budgeting practices, which leads to the research question:

$\mathrm{RQ}_{2}$ : Is there any significant difference the capital budgeting practices used in different industries?

And thus, it can be hypothesised that:

$\mathrm{H}_{2}$ : Non manufacturing firms use simple capital budgeting practices.

Hornstein (2013) found that managers and financial officers significantly influence corporate behavior and performance. In particular, the educational qualifications of financial officers have been recognized as a determinant of capital budgeting practice (Graham \& Harvey, 2001). There is a general consensus that a financial officer with a higher level of education will have fewer problems in understanding more sophisticated capital budgeting techniques and thus they will be capable of using them. A positive relationship has been identified between the educational background of financial officers and the use of sophisticated methods (Hermes et al.,2007). Among the U.S. sample, a positive association was found between chief financial officers' education and the use of sophisticated capital budgeting practices (Graham \& Harvey, 2001) and these findings were consistent with those in the Netherlands, Germany and France, but not in the UK (Brounen et al., 2004). There is a dearth of studies in emerging counties on the relationship between financial officers' educational qualifications and the choice of capital budgeting practices and the results found in developed countries are not consistent with previous studies (e.g., Brounen et al., 2004), leading to a research question: 
$\mathrm{RQ}_{3}$ : Is there any significant difference between the educational qualification of financial officers' and firms' capital budgeting practices?

And thus, it can be hypothesised that:

$\mathrm{H}_{3}$ : Financial officers with higher educational qualifications use more sophisticated capital budgeting practices.

Besides the educational qualifications of financial officers, their experience might also determine their choice of capital budgeting practice. However, a handful of research studies have reported that the experience of financial officers will determine the use of capital budgeting methods since over time they become more familiar with more sophisticated capital budgeting methods (e.g., Hermes et al., 2007; Verma et al., 2009) And thus, this study raises the research question:

$\mathrm{RQ}_{4}$ : Is there any significant difference between years of experience of financial officers and their capital budgeting practices?

And thus, it can be hypothesised that:

$\mathrm{H}_{4}$ : $\quad$ Financial officers with a short tenure use simple capital budgeting practices.

\section{Methods}

\section{Sample}

287 companies were listed on the Colombo stock exchange in Sri Lanka as at 31.12.2013. From the 287, 186 companies responded to the survey. Although the people who make capital budgeting decisions in Sri Lanka are named chief financial officers, chief executive officers, financial controllers, finance managers, management accountants, and financial directors, this research commonly refers to them as financial officers. The self-report questionnaire was designed and emailed to the respondents, some were directly distributed and some were posted to financial officers.

\section{Data sources}

The relevant data for the purpose of this study were garnered from primary sources.

The primary source of data collection- The questionnaire

A questionnaire was administered to collect the primary data. The questionnaire elicited information regarding the company's demographic information (including the respondent's qualifications, experience and type of industry) and corporate practices regarding capital budgeting, including the size of the capital budget, the capital budgeting technique and supplementary capital budgeting tools for incorporating risk. The questions measuring the capital budgeting practices were adopted from previous seminal studies (Arnold \& Hatzopoulos, 2000; Graham \& Harvey, 2001; Brounen et al., 2004; Hermes et al., 2007; Verma et al., 2009). Nonetheless, fundamental changes were made to the questionnaire in order to fit with the Sri Lankan context. The questionnaire survey was carried during the period from June to December 2013. 


\section{Data Analysis}

Following paragraphs intend to answer the research question concerning do firms' characteristics make a difference of the choice of capital budgeting practices. Firstly, descriptive analysis of survey responses is presented including educational qualification of the financial officers, experience of the financial officers, types of industry, and size of the capital budget. Secondly, analysis focuses on the identification of prevailing capital budgeting practices in Sri Lanka. Thirdly, firms' characteristics are examined to see the differences in the choice of capital budgeting practices.

Descriptive analysis of the survey responses

\section{Educational qualification of the financial officers}

Classification of the educational qualification of the financial officers was grouped into: bachelor degree, MBA, non-MBA Master's, above Master's degree and professional qualification. Above master degree qualification (e.g., MPhil/PhD or master degree with professional qualification) was held by $52.2 \%$ of Financial officers, followed by MBA qualification (29\%), non-MBA Master's (13.4\%), Bachelor degree (3.8\%) and professional qualification $(1.6 \%)$.

Further to such general classification, the educational qualification of the financial officers was regrouped into two for analytical purposes: MBA-level and above and non-MBA and other. The MBA-level and above includes both MBA and above Master's degree whereas non-MBA and other includes Bachelor degree, non-MBA Master's and professional qualification. The classifications were in line with Graham and Harvey (2001) and Brounen et al.(2004).

\section{Experience of the financial officers}

Experience of the financial officers was classified into four groups in terms of number of years they had been in the profession: less than 5 years, 5-9 years, 10-19 years and 20 years and more. The higher number of financial officers had 10 to 19 years' experience $(N=81)$, followed by 20 years' and more experience $(N=77), 5$ to 9 years' $(N=21)$ and a small number of financial officers had less than 5 years' experience $(N=7)$.

For analytical purposes, experience of Financial officers was regrouped into two in line with Graham and Harvey (2001) and Brounen et al.(2004): short tenure and long tenure. The short tenure includes both less than 5 years' experience and 5-9 years' experience whereas long tenure includes both 10-19 years' experience and 20 and more years' experience.

Types of industry

Types of industry were initially classified in terms of their nature (Verbeeten, 2006) as shown in table 1: financial service industry, manufacturing industry, diversified holdings, health care industry, hotel industry and other non-financial industry. As can be seen in the table, 52.7\% of industries are manufacturing, followed by other non-financial industry (17.7\%), hotel 
industry (15.6\%), diversified holdings (5.9\%), financial service industry $(4.8 \%)$ and health care industry $(3.2 \%)$.

Table 1. Types of industry

Industries

No. of

Companies $(N)$

Percentage $(\%)$

Financial Service Industry (e.g., bank, finance and insurance- FINSERV)

$9 \quad 4.8 \%$

Manufacturing Industry (e.g., beverages, food \& tobacco, chemical \& pharmaceutical, construction and engineering, foot ware and textile, manufacturing, power 98 $52.7 \%$ and energy motors, oil palms, plantations and tradingMFTG)

Diversified Holdings (DIVERS) $11 \quad 5.9 \%$

Health care Industry (HEALTH) $6 \quad 3.2 \%$

Hotel Industry (HOTEL)

Other Non-Financial Industry (e.g., investment trust, land and property, services, stores and supplies and 33 $17.7 \%$ telecommunications (OTNFIN)

\begin{tabular}{llll}
\hline Total & 186 & $100.0 \%$ \\
\hline
\end{tabular}

Nonetheless, for analytical purposes as suggested by Graham and Harvey (2001) and Brounen et al. (2004), they were regrouped into "manufacturing" and "non-manufacturing".

\section{Size of capital budget}

Size of capital budget was categorised into five groups in line with Verma et al. (2009): less than LKR 10 million, LKR 1-99 million, LKR 100-499 million, LKR 500 -999 million and LKR 1 billion and over. The large number of Financial officers reported that size of their capital budget is between LKR $100-499$ million (39.2\%), followed by LKR 10-99 million (27.4\%), LKR 1 billion and over (14\%), LKR 500-999 million (10.2\%) and less than LKR 10 million $(9.1 \%)$.

For analytical purposes, sizes of capital budget were regrouped into "large" and "small" in line with Graham and Harvey (2001) and Brounen et al.(2004). Firms with capital budget greater than LKR 1 billion is considered as "large" and less than LKR 1 billion is considered as "small"

\section{Capital budgeting practices}

There is a tendency to use multi-methods in making capital budgeting decisions (e.g., Arnold \& Hatzopoulos, 2000). As a caveat, prevalent capital budgeting decision tools, namely capital 
budgeting methods and capital budgeting tools incorporating risk in Sri Lanka, were subjected to principal component analysis with Varimax rotation in line with many research scholars (e.g., Verbeeten, 2006). The results are presented in table 2.

Table 2. Total variance explained for the factors indicating to the capital budgeting practices

\begin{tabular}{|l|c|c|c|}
\hline \multirow{2}{*}{} & \multicolumn{2}{|c|}{ Factors } \\
\cline { 2 - 4 } & Advanced / NPV Based & Sophisticated Capital & Simple/ Naïve \\
& Capital Budgeting & Budgeting Practices & Capital Budgeting \\
Eigen Value & Practices & 2.108 & 1.365 \\
Proportion of Variance Explained & 5.822 & $14.052 \%$ & $9.101 \%$ \\
Cumulative Percentage Explained & $38.815 \%$ & $52.867 \%$ & $61.968 \%$ \\
Cronbach's Alpha - Reliability of & $38.815 \%$ & 0.809 & 0.744 \\
\hline
\end{tabular}

As can be seen in table 2, prevalent capital budgeting practices in Sri Lanka were grouped into three, in line with the literature: Advanced capital budgeting practices include probability analysis, internal rate of return, scenario analysis, adjusting required return, uncertainty absorption in cash flows, sensitivity analysis and net present value; sophisticated capital budgeting practices include real option, CAPM $/ \beta$ analysis, game theory decisions and decision trees, and simple/naive capital budgeting practices include discounted payback , accounting rate of return and payback (e.g., Verbeeten, 2006; Wolffsen, 2012).

Table 3 shows use of capital budgeting practices in Sri Lanka. 


\section{Macrothink}

Table 3. Capital budgeting practices in Sri Lanka

\begin{tabular}{|c|c|c|c|c|c|c|}
\hline & Never & Rarely & Sometimes & Often & Always & Mean \\
\hline \multicolumn{7}{|l|}{ Naive capital budgeting practices } \\
\hline Discounted Payback Period (DPB) & $1.1 \%$ & $10.8 \%$ & $64.0 \%$ & $24.2 \%$ & - & 3.11 \\
\hline Accounting Rate of Return (ARR) & $3.8 \%$ & $13.4 \%$ & $61.8 \%$ & $19.9 \%$ & $1.1 \%$ & 3.01 \\
\hline Payback Period (PB) & $2.2 \%$ & $13.4 \%$ & $34.4 \%$ & $37.6 \%$ & $12.4 \%$ & 3.45 \\
\hline \multicolumn{7}{|l|}{ Advanced capital budgeting practices } \\
\hline Probability Analysis (PA) & $1.1 \%$ & $3.2 \%$ & $13.4 \%$ & $68.8 \%$ & $13.4 \%$ & 3.90 \\
\hline Scenario Analysis (SA) & $1.6 \%$ & $5.4 \%$ & $12.4 \%$ & $65.1 \%$ & $15.6 \%$ & 3.88 \\
\hline Adjusting required return & $2.7 \%$ & $5.9 \%$ & $14.0 \%$ & $63.4 \%$ & $14.0 \%$ & 3.80 \\
\hline Internal Rate of Return (IRR) & $6.5 \%$ & $5.9 \%$ & $8.6 \%$ & $55.9 \%$ & $23.1 \%$ & 3.83 \\
\hline Uncertainty absorption in cash flows & $0.5 \%$ & $1.6 \%$ & $12.4 \%$ & $69.9 \%$ & $15.6 \%$ & 3.98 \\
\hline Sensitivity Analysis (SA) & $1.6 \%$ & $8.1 \%$ & $11.3 \%$ & $52.7 \%$ & $26.3 \%$ & 3.94 \\
\hline Net Present Value (NPV) & $1.6 \%$ & $2.2 \%$ & $12.4 \%$ & $51.6 \%$ & $32.3 \%$ & 4.11 \\
\hline \multicolumn{7}{|l|}{$\begin{array}{l}\text { Sophisticated capital budgeting } \\
\text { practices }\end{array}$} \\
\hline Real Options (RO) & $78.0 \%$ & $15.6 \%$ & $6.5 \%$ & - & - & 1.28 \\
\hline Game Theory Decisions (GTD) & $83.9 \%$ & $26.0 \%$ & $2.2 \%$ & - & - & 1.18 \\
\hline Decision Trees (DT) & $65.6 \%$ & $27.4 \%$ & $7.0 \%$ & - & - & 1.41 \\
\hline CAPM $/ \beta$ Analysis & $77.4 \%$ & $11.8 \%$ & $8.6 \%$ & $2.2 \%$ & - & 1.35 \\
\hline
\end{tabular}

As can be seen in table 3, NPV was the most preferred method of capital budgeting, $83.9 \%$ of the financial officers 'always and often' preferred it, yielding a mean value of 4.11. This was followed by Uncertainty absorption in cash flows which was 'always and often' preferred by $85.5 \%(M=3.98)$. Sensitivity Analysis was the next 'always and often' preferred method by $78 \%(M=3.94)$ followed by Probability Analysis with $82.2 \%(M=3.90)$, Scenario Analysis with $80.7 \%(M=3.88)$, Internal Rate of Return with $79 \%(M=3.83)$, Adjusting required return with $77.4 \%(M=3.80)$, PB with $50 \%(M=3.45)$, DPB with $24.2 \%(M=3.11)$ and ARR with $21 \%(M=3.01)$. Methods such as RO, GTD, decision tree and CAPM/ $\beta$ Analysis were not popular, yielding mean values of less than 2.0.

\section{Firms’ characteristics and capital budgeting practices}

The current survey carefully considered the underlying firm characteristics in order to find out the differences in the use/choice of capital budgeting practices: size of capital budget, educational qualification of financial officers, experience of financial officers and types of industry. The mean difference statistics of independent sample $t$-test was employed. 


\section{Size of capital budgets and use of capital budgeting practices}

As aforesaid, size of capital budgets were grouped into "small" and "large". The results of the independent sample $t$-test between size of capital budgets and use of capital budgeting practices are presented in table 4.

Table 4. Size of capital budgets and use of capital budgeting practices

\begin{tabular}{|c|c|c|c|c|c|c|c|c|}
\hline Capital budgeting practices & $\begin{array}{c}\text { Size of the capital } \\
\text { budget }\end{array}$ & $N$ & $d f$ & Mean & SD & SE & $t$ & sig \\
\hline PB & $\begin{array}{l}\text { Small } \\
\text { Large }\end{array}$ & $\begin{array}{l}160 \\
26\end{array}$ & 184 & $\begin{array}{l}3.63 \\
2.35\end{array}$ & $\begin{array}{l}.867 \\
.629\end{array}$ & $\begin{array}{l}.069 \\
.123\end{array}$ & 9.064 & 0.000 \\
\hline DPB & $\begin{array}{l}\text { Small } \\
\text { Large }\end{array}$ & $\begin{array}{l}160 \\
26\end{array}$ & 184 & $\begin{array}{l}3.18 \\
2.73\end{array}$ & $\begin{array}{l}.578 \\
.724\end{array}$ & $\begin{array}{l}.046 \\
.142\end{array}$ & 2.977 & 0.000 \\
\hline ARR & $\begin{array}{l}\text { Small } \\
\text { Large }\end{array}$ & $\begin{array}{l}160 \\
26\end{array}$ & 184 & $\begin{array}{l}3.13 \\
2.31\end{array}$ & $\begin{array}{l}.652 \\
.788\end{array}$ & $\begin{array}{l}.052 \\
.155\end{array}$ & 5.754 & 0.000 \\
\hline NPV & $\begin{array}{l}\text { Small } \\
\text { Large }\end{array}$ & $\begin{array}{l}160 \\
26\end{array}$ & 184 & $\begin{array}{l}3.97 \\
4.96\end{array}$ & $\begin{array}{l}.796 \\
.196\end{array}$ & $\begin{array}{l}.063 \\
.038\end{array}$ & -6.312 & 0.000 \\
\hline IRR & $\begin{array}{l}\text { Small } \\
\text { Large }\end{array}$ & $\begin{array}{l}160 \\
26\end{array}$ & 184 & $\begin{array}{l}3.73 \\
4.50\end{array}$ & $\begin{array}{r}1.046 \\
.860\end{array}$ & $\begin{array}{l}.083 \\
.169\end{array}$ & -4.125 & 0.000 \\
\hline RO & $\begin{array}{l}\text { Small } \\
\text { Large }\end{array}$ & $\begin{array}{l}160 \\
26\end{array}$ & 184 & $\begin{array}{l}1.13 \\
2.23\end{array}$ & $\begin{array}{l}.357 \\
.765\end{array}$ & $\begin{array}{l}.028 \\
.150\end{array}$ & -11.947 & 0.000 \\
\hline GTD & $\begin{array}{l}\text { Small } \\
\text { Large }\end{array}$ & $\begin{array}{l}160 \\
26\end{array}$ & 184 & $\begin{array}{l}1.08 \\
1.81\end{array}$ & $\begin{array}{l}.274 \\
.694\end{array}$ & $\begin{array}{l}.022 \\
.136\end{array}$ & -9.516 & 0.000 \\
\hline Sensitivity Analysis & $\begin{array}{l}\text { Small } \\
\text { Large }\end{array}$ & $\begin{array}{l}160 \\
26\end{array}$ & 184 & $\begin{array}{l}3.79 \\
4.85\end{array}$ & $\begin{array}{l}.898 \\
.368\end{array}$ & $\begin{array}{l}.071 \\
.072\end{array}$ & -5.886 & 0.000 \\
\hline Scenario Analysis & $\begin{array}{l}\text { Small } \\
\text { Large }\end{array}$ & $\begin{array}{l}160 \\
26\end{array}$ & 184 & $\begin{array}{l}3.84 \\
4.08\end{array}$ & $\begin{array}{l}.797 \\
.744\end{array}$ & $\begin{array}{l}.063 \\
.146\end{array}$ & -1.467 & 0.151 \\
\hline Decision Trees & $\begin{array}{l}\text { Small } \\
\text { Large }\end{array}$ & $\begin{array}{l}160 \\
26\end{array}$ & 184 & $\begin{array}{l}1.26 \\
2.35\end{array}$ & $\begin{array}{l}.441 \\
.745\end{array}$ & $\begin{array}{l}.035 \\
.146\end{array}$ & -10.379 & 0.000 \\
\hline $\mathrm{CAPM} / \beta$ Analysis & $\begin{array}{l}\text { Small } \\
\text { Large }\end{array}$ & $\begin{array}{l}160 \\
26\end{array}$ & 184 & $\begin{array}{l}1.16 \\
2.58\end{array}$ & $\begin{array}{r}.413 \\
1.027\end{array}$ & $\begin{array}{l}.033 \\
.201\end{array}$ & -12.467 & 0.000 \\
\hline $\begin{array}{l}\text { Uncertainty absorption in cash } \\
\text { flows }\end{array}$ & $\begin{array}{l}\text { Small } \\
\text { Large }\end{array}$ & $\begin{array}{l}160 \\
26\end{array}$ & 184 & $\begin{array}{l}3.91 \\
4.46\end{array}$ & $\begin{array}{l}.570 \\
.761\end{array}$ & $\begin{array}{l}.045 \\
.149\end{array}$ & -4.383 & 0.000 \\
\hline Adjusting required return & $\begin{array}{l}\text { Small } \\
\text { Large }\end{array}$ & $\begin{array}{l}160 \\
26\end{array}$ & 184 & $\begin{array}{l}3.76 \\
4.08\end{array}$ & $\begin{array}{l}.867 \\
.688\end{array}$ & $\begin{array}{l}.069 \\
.135\end{array}$ & -2.118 & 0.041 \\
\hline Probability Analysis & $\begin{array}{l}\text { Small } \\
\text { Large }\end{array}$ & $\begin{array}{l}160 \\
26\end{array}$ & 184 & $\begin{array}{l}3.88 \\
4.04\end{array}$ & $\begin{array}{l}.704 \\
.662\end{array}$ & $\begin{array}{l}.056 \\
.130\end{array}$ & -1.065 & 0.288 \\
\hline
\end{tabular}


As can be seen in table 4, small firms more highly applied the payback method $(M=3.63$, $S E=.06)$ than large firms $(M=2.35, S E=.12)$. The difference was significant $t(184)=9.064, p$ $<0.01$. A similar pattern was observed in the application of DPB and ARR that small firms more highly applied DPB and $\operatorname{ARR}(M=3.18, S E=.04 ; M=3.13, S E=.05)$ than large firms $(M=2.73, S E=.142 ; M=2.31, S E=.155)$ and the differences were also significant $t(184)=$ $2.877, p<0.01$ and $t(184)=5.754, p<0.01$ respectively. Therefore, it is fair to say that simple capital budgeting practices $\mathrm{PB}, \mathrm{DPB}$ and ARR were more highly applied by small firms in comparison with large firms. As to advanced capital budgeting practices, NPV and IRR are more highly significantly applied by large firms $(M=4.96, S E=.038 ; M=4.50$, $S E=.169)$ than small firms $(M=3.97, S E=.063 ; M=3.73, S E=.083)$ and the significant mean differences were found $t(184)=-6.312, p<0.01, t(184)=-4.125, p<0.01$, respectively. As regard to sophisticated capital budgeting practices, RO, GTD are also highly applied by large companies $(M=2.23, S E=.150 ; M=1.81, S E=.136)$ than small companies $(M=1.13, S E=.028$; $M=1.08, S E=.022)$ and the significant differences were RO and GTD, respectively $t(184)=$ $-11.947, p<0.01, t(184)=-9.516, p<0.01$.

In the case of sensitivity analysis, uncertainty absorption in cash flows and adjusting required return were significantly highly applied by large firms $(M=4.85, S E=.072 ; M=4.46, S E=.149$, and $M=4.08, S E=.135)$ than small companies $(M=3.79, S E=.071 ; M=3.91, S E=.045$, and $M=3.76, S E=.069)$ and the significant differences were found $t(184)=-5.886, p<0.01, t$ $(184)=-4.383, p<0.01$ and $t(184)=-2.118, p<0.041$, respectively. Although scenario analysis and probability analysis were highly applied by large firms, the differences were not statistically significant at $p<0.05$. Moreover, CAPM $/ \beta$ analysis and decision trees were also more highly applied by large companies $(M=2.58, S E=.201 ; M=2.35, S E=.146)$ than small companies $(M=1.16, S E=.033 ; M=1.26, S E=.035)$ and the differences were significant $t(184)$ $=-12.467, p<0.01, t(184)=-10.379, p<0.01$.

Therefore, simple capital (naive) budgeting practices were significantly mostly used by small firms, nonetheless, advanced and sophisticated capital budgeting practices were significantly mostly used by large firms. Consequently, hypothesis $\left(H_{1}\right)$ that simple capital budgeting practices are used when a firm's capital budget is small was supported.

\section{Types of industry and use of capital budgeting methods}

This section draws attention to the differences between types of industry and capital budgeting methods. Types of industry were grouped into non-manufacturing (NMANU) and manufacturing (MANU) in line with Graham and Harvey (2001). The results of an independent sample $t$-test are presented in table 5. 
Table 5. Types of industry and use of capital budgeting practices

\begin{tabular}{|c|c|c|c|c|c|c|c|c|}
\hline Capital budgeting practices & Industry & $N$ & $d f$ & Mean & $\mathrm{SD}$ & SE & $t$ & sig \\
\hline \multirow{2}{*}{ PB } & NMANU & 88 & & 3.49 & .971 & .103 & & \\
\hline & MANU & 98 & 184 & 3.41 & .929 & .094 & .577 & .564 \\
\hline \multirow{2}{*}{ DPB } & NMANU & 88 & & 3.15 & .635 & .068 & & \\
\hline & MANU & 98 & 184 & 3.08 & .604 & .061 & .727 & .468 \\
\hline \multirow{2}{*}{ ARR } & NMANU & 88 & & 3.11 & .718 & .077 & & \\
\hline & MANU & 98 & 184 & 2.92 & .728 & .073 & 1.839 & .048 \\
\hline \multirow{2}{*}{ NPV } & NMANU & 88 & & 4.18 & .891 & .095 & & \\
\hline & MANU & 98 & 184 & 4.04 & .745 & .075 & 1.175 & .242 \\
\hline \multirow{2}{*}{ IRR } & NMANU & 88 & & 3.88 & 1.059 & .113 & & \\
\hline & MANU & 98 & 184 & 3.80 & 1.055 & .107 & .509 & .611 \\
\hline \multirow{2}{*}{ RO } & NMANU & 88 & & 1.34 & .604 & .064 & & \\
\hline & MANU & 98 & 184 & 1.23 & .552 & .056 & 1.252 & .212 \\
\hline \multirow{2}{*}{ GTD } & NMANU & 88 & & 1.17 & .407 & .043 & & \\
\hline & MANU & 98 & 184 & 1.19 & .469 & .047 & -.362 & .718 \\
\hline \multirow{2}{*}{ Sensitivity Analysis } & NMANU & 88 & & 4.00 & .935 & .100 & & \\
\hline & MANU & 98 & 184 & 3.89 & .907 & .092 & .831 & .407 \\
\hline \multirow{2}{*}{ Scenario Analysis } & NMANU & 88 & & 3.89 & .794 & .085 & & \\
\hline & MANU & 98 & 184 & 3.87 & .795 & .080 & .163 & .871 \\
\hline \multirow{2}{*}{ Decision Trees } & NMANU & 88 & & 1.44 & .641 & .068 & & \\
\hline & MANU & 98 & 184 & 1.39 & .603 & .061 & .608 & .544 \\
\hline \multirow{2}{*}{ CAPM/ $\beta$ Analysis } & NMANU & 88 & & 1.32 & .670 & .071 & & \\
\hline & MANU & 98 & 184 & 1.39 & .782 & .079 & -.648 & .518 \\
\hline \multirow{2}{*}{$\begin{array}{l}\text { Uncertainty absorption in cash } \\
\text { flows }\end{array}$} & NMANU & 88 & & 3.93 & .708 & .075 & & \\
\hline & MANU & 98 & 184 & 4.03 & .546 & .055 & -1072 & .285 \\
\hline \multirow{2}{*}{ Adjusting required return } & NMANU & 88 & & 3.83 & .887 & .095 & & \\
\hline & MANU & 98 & 184 & 3.78 & .819 & .083 & .432 & .666 \\
\hline \multirow{2}{*}{ Probability Analysis } & NMANU & 88 & & 3.88 & .724 & .077 & & \\
\hline & MANU & 98 & 184 & 3.93 & .677 & .068 & .294 & .603 \\
\hline
\end{tabular}

As can be seen in table 5, only ARR was statistically significant and mostly applied by non-manufacturing firms $(M=3.11, S E=.077)$ than manufacturing firms $(M=2.92, S E=.073)$ at $t(184)=1.839, p<0.05$. Save for ARR, all other capital budgeting practices were not statistically significant with type of industry $(p>0.05)$.

Therefore, in all cases except ARR, type of industry was not significantly different on use of capital budgeting practices. The results only supported the notion that the use of ARR was significantly greater in non-manufacturing firms than in manufacturing firms. Therefore, 


\section{Macrothink}

Asian Journal of Finance \& Accounting ISSN 1946-052X 2017, Vol. 9, No. 2

hypothesis $\left(\mathrm{H}_{2}\right)$ that non manufacturing firms use simple capital budgeting practices was supported that ARR was mostly used by non manufacturing companies.

Education qualifications of financial officers and use of capital budgeting practices

The educational qualifications of financial officers were grouped into MBA and non-MBA qualifications in line with Graham and Harvey (2001). An independent sample $t$-test was performed to see the difference between educational qualification of financial officers and the use of capital budgeting practices. The results are presented in table 6 . 
Table 6. Education qualifications and use of capital budgeting practices

\begin{tabular}{|c|c|c|c|c|c|c|c|c|}
\hline Capital budgeting practices & Educational qualifications & $N$ & $d f$ & Mean & SD & $\mathrm{SE}$ & $t$ & sig \\
\hline \multirow{2}{*}{ PB } & Non-MBA & 35 & & 3.91 & .781 & .132 & & \\
\hline & MBA & 151 & 184 & 3.34 & .951 & .077 & 3.332 & .001 \\
\hline \multirow{2}{*}{ DPB } & Non-MBA & 35 & & 3.37 & .598 & .101 & & \\
\hline & MBA & 151 & 184 & 3.05 & .609 & .050 & 2.828 & .007 \\
\hline \multirow{2}{*}{ ARR } & Non-MBA & 35 & & 3.37 & .690 & .117 & & \\
\hline & MBA & 151 & 184 & 2.93 & .713 & .058 & 3.412 & .001 \\
\hline \multirow{2}{*}{ NPV } & Non-MBA & 35 & & 3.06 & .873 & .147 & & \\
\hline & MBA & 151 & 184 & 4.35 & .580 & .047 & -8.356 & .000 \\
\hline \multirow{2}{*}{ IRR } & Non-MBA & 35 & & 2.60 & 1.193 & .202 & & \\
\hline & MBA & 151 & 184 & 4.12 & .783 & .064 & -9.275 & .000 \\
\hline \multirow{2}{*}{ RO } & Non-MBA & 35 & & 1.09 & .284 & .048 & & \\
\hline & MBA & 151 & 184 & 1.33 & .619 & .050 & -2.287 & .023 \\
\hline \multirow{2}{*}{ GTD } & Non-MBA & 35 & & 1.06 & .236 & .040 & & \\
\hline & MBA & 151 & 184 & 1.21 & .471 & .038 & -2.802 & .006 \\
\hline \multirow{2}{*}{ Sensitivity Analysis } & Non-MBA & 35 & & 2.97 & .985 & .166 & & \\
\hline & MBA & 151 & 184 & 4.17 & .743 & .060 & -6.743 & .000 \\
\hline \multirow{2}{*}{ Scenario Analysis } & Non-MBA & 35 & & 3.03 & .857 & .145 & & \\
\hline & MBA & 151 & 184 & 4.07 & .634 & .052 & -8.182 & .000 \\
\hline \multirow{2}{*}{ Decision Trees } & Non-MBA & 35 & & 1.17 & .382 & .065 & & \\
\hline & MBA & 151 & 184 & 1.47 & .651 & .053 & -2.608 & .010 \\
\hline \multirow{2}{*}{ CAPM/ $\beta$ Analysis } & Non-MBA & 35 & & 1.14 & .355 & .060 & & \\
\hline & MBA & 151 & 184 & 1.40 & .785 & .064 & -2.980 & .003 \\
\hline \multirow{2}{*}{ Uncertainty absorption in cash flows } & Non-MBA & 35 & & 3.34 & .765 & .129 & & \\
\hline & MBA & 151 & 184 & 4.13 & .485 & .040 & -7.682 & .000 \\
\hline \multirow{2}{*}{ Adjusting required return } & Non-MBA & 35 & & 2.97 & .985 & .166 & & \\
\hline & MBA & 151 & 184 & 3.99 & .688 & .056 & -7.247 & .000 \\
\hline \multirow{2}{*}{ Probability Analysis } & Non-MBA & 35 & & 3.26 & .701 & .118 & & \\
\hline & MBA & 151 & 184 & 4.05 & .609 & .050 & -6.769 & .000 \\
\hline
\end{tabular}

As shown in table 6, simple capital budgeting practices PB, DPB and ARR were more highly applied by non-MBA financial officers $(M=3.91, S E=.132 ; M=3.37, S E=.101$, and $M=3.37$, $S E=.117)$ and the differences were significant $t(184)=3.332, p<0.01, t(184)=2.828, p<$ 0.01 and $t(184)=3.412, p<0.01$, respectively. In the case of advanced capital budgeting practices, NPV and IRR were highly applied by financial officers who had MBA qualifications $(M=4.35, S E=.047 ; M=4.12, S E=.064)$ than non MBA Financial officers $(M=3.06, S E=.147 ; M=2.60, S E=.202)$ and the differences were significant $t(184)=-8.356$, 
$p<0.01, t(184)=-9.275, p<0.01$, respectively. A similar pattern was observed in sophisticated capital budgeting practices. RO and GTD were also more highly applied by financial officers who had an MBA $(M=1.33, S E=.050 ; M=1.21, S E=.038)$ than non-MBA financial officers $(M=1.09, S E=.048 ; M=1.06, S E=.040)$ and the significant differences were found $t(184)=-2.287, p<0.05, t(184)=-2.802, p<0.01$, respectively.

As for sensitivity analysis, scenario analysis, uncertainty absorption in cash flows, adjusting required return and probability analysis were significantly more highly applied by financial officers who had an MBA $(M=4.17, S E=.060 ; M=4.07, S E=.052, M=4.13, S E=.040, M=3.99$, $S E=.052$ and $M=4.05, S E=.050)$ than non-MBAs Financial officers $(M=2.97, S E=.166 ; M$ $=3.03, S E=.145, M=3.34, S E=.329, M=2.97, S E=.166$ and $M=3.26, S E=.118)$ at $t(184)=$ $-6.743, p<0.01, t(184)=-8.182, p<0.01, t(184)=-7.682, p<0.01, t(184)=-7.247, p<$ 0.01 and $t(184)=-6.769, p<0.01$, respectively. Moreover, CAPM/ $\beta$ analysis and decision trees were more highly applied by financial officers with MBAs $(M=1.40, S E=.064 ; M=1.47$, $S E=.053)$ than financial officers with non-MBAs $(M=1.14, S E=.060 ; M=1.17, S E=.065)$ and the differences were significant $t(184)=-2.980, p<0.01, \mathrm{t}(184)=-2.608, p<0.01$, respectively.

Therefore, simple capital (naive) budgeting practices were significantly mostly used by financial officers with non-MBA qualification, nonetheless, advanced and sophisticated capital budgeting practices were significantly mostly used by financial officers with MBA qualifications. Consequently, hypothesis $\left(\mathrm{H}_{3}\right)$ that Chief Financial Officers with higher educational qualifications use more sophisticated capital budgeting practices was supported.

Experience of financial officers and use of capital budgeting practices

This section examines the difference in use of capital budgeting practice in terms of the experience of the financial officers (tenure). The tenure was grouped into "short" and "long" in line with Graham and Harvey (2001). Table 7 shows the results of the independent sample $t$-test. 
Table 7. Tenure and use of capital budgeting practices

\begin{tabular}{|c|c|c|c|c|c|c|c|c|}
\hline Capital budgeting practices & Tenure & $N$ & $d f$ & Mean & SD & SE & $t$ & $\operatorname{sig}$ \\
\hline \multirow{2}{*}{ PB } & Short & 28 & & 3.79 & .630 & .119 & & \\
\hline & Long & 158 & 184 & 3.39 & .982 & .078 & 2.076 & .039 \\
\hline \multirow{2}{*}{ DPB } & Short & 28 & & 3.18 & .548 & .104 & & \\
\hline & Long & 158 & 184 & 3.10 & .630 & .050 & 0.609 & .543 \\
\hline \multirow{2}{*}{ ARR } & Short & 28 & & 3.14 & .803 & .152 & & \\
\hline & Long & 158 & 184 & 2.99 & .714 & .057 & 1.042 & .299 \\
\hline \multirow{2}{*}{ NPV } & Short & 28 & & 3.75 & .799 & .151 & & \\
\hline & Long & 158 & 184 & 4.17 & .808 & .064 & -2.546 & .012 \\
\hline \multirow{2}{*}{ IRR } & Short & 28 & & 3.64 & .870 & .164 & & \\
\hline & Long & 158 & 184 & 3.87 & 1.083 & .086 & -1.037 & .301 \\
\hline \multirow{2}{*}{ RO } & Short & 28 & & 1.11 & .315 & .060 & & \\
\hline & Long & 158 & 184 & 1.32 & .609 & .048 & -2.728 & .008 \\
\hline \multirow{2}{*}{ GTD } & Short & 28 & & 1.00 & .000 & .000 & & \\
\hline & Long & 158 & 184 & 1.22 & .470 & .037 & -5.755 & .000 \\
\hline \multirow{2}{*}{ Sensitivity Analysis } & Short & 28 & & 3.68 & .863 & .163 & & \\
\hline & Long & 158 & 184 & 3.99 & .924 & .073 & -1.726 & .092 \\
\hline \multirow{2}{*}{ Scenario Analysis } & Short & 28 & & 3.79 & .568 & .107 & & \\
\hline & Long & 158 & 184 & 3.89 & .826 & .066 & -0.656 & .513 \\
\hline \multirow{2}{*}{ Decision Trees } & Short & 28 & & 1.11 & .315 & .060 & & \\
\hline & Long & 158 & 184 & 1.47 & .645 & .051 & -2.897 & .004 \\
\hline \multirow{2}{*}{ CAPM/ $/ \beta$ Analysis } & Short & 28 & & 1.11 & .315 & .060 & & \\
\hline & Long & 158 & 184 & 1.40 & .773 & .062 & -3.406 & .001 \\
\hline \multirow{2}{*}{ Uncertainty absorption in cash flows } & Short & 28 & & 3.64 & .731 & .138 & & \\
\hline & Long & 158 & 184 & 4.04 & .590 & .047 & -3.194 & .002 \\
\hline \multirow{2}{*}{ Adjusting required return } & Short & 28 & & 3.64 & .911 & .172 & & \\
\hline & Long & 158 & 184 & 3.83 & .839 & .067 & -1.069 & .286 \\
\hline \multirow{2}{*}{ Probability Analysis } & Short & 28 & & 3.79 & .568 & .107 & & \\
\hline & Long) & 158 & 184 & 3.92 & .719 & .057 & -1.137 & .262 \\
\hline
\end{tabular}

As can be seen in table 7, simple capital budgeting practices PB, DPB and ARR were applied more by financial officers with short tenure $(M=3.79, S E=.119 ; M=3.18, S E=.104$, and $M=3.14, S E=152)$ than financial officers with long tenure financial officers $(M=3.39$, $S E=.078 ; M=3.10, S E=.050$, and $M=2.99, S E=.057$ ), however, the difference was only significant for PB $t(184)=2.076, p<0.05$. Similarly, for advanced capital budgeting practices, NPV and IRR were mostly more used by financial officers with long tenure $(M=4.17, S E=.064 ; M=3.87, S E=.086)$ than financial officers with short tenure $(M=3.75$, 
$S E=.151 ; M=3.64, S E=.164)$, nonetheless, the difference was only significant for NPV ( $t$ (184) $=-2.546, p<0.05$. In the case of sophisticated capital budgeting practices, RO and GTD were also mostly more applied by financial officers with long tenure $(M=1.32, S E=.048 ; M=1.22$, $S E=.037)$ than financial officers with short tenure $(M=1.11, S E=.060 ; M=1.00, S E=.000)$ and the differences were significant $t(184)=-2.728, p<0.01, t(184)=-5.755, p<0.01$, respectively. $\mathrm{CAPM} / \beta$ analysis and decision trees were more highly applied by financial officers with long tenure $(M=1.40, S E=.062 ; M=1.47, S E=.051)$ than financial officers with short tenure $(M=1.11, S E=.060 ; M=1.11, S E=.060)$ and the differences were significant $t(184)$ $=-3.406, p<0.01, t(184)=-2.897, p<0.01$, respectively. Uncertainty absorption in cash flows was also more highly significantly applied by financial officers with long tenure $(M=4.04, S E=.047)$ than financial officers with short tenure $(M=3.64, S E=.138)$ at $t(184)=$ $-3.194, p<0.01$. Notwithstanding that sensitivity analysis, scenario analysis, adjusting required return and probability analysis were mostly used by financial officers with long tenure, they were not statistically significant.

Therefore, in all cases, simple capital (naive) budgeting practices were mostly used by financial officers with short tenure (significantly different only for PB), nonetheless, advanced and sophisticated capital budgeting practices (NPV, RO, GTD, uncertainty absorption in cash flows, decision trees and CAPM/ $\beta$ analysis) were significantly mostly used by financial officers with long tenure. Consequently, hypothesis $\left(\mathrm{H}_{4}\right)$ that financial officers with a short tenure use simple capital budgeting practices was supported.

\section{Conclusion}

The differences of the firms' characteristics on the application of capital budgeting practices were examined in this study. 186 Sri Lankan firms were responded to the survey and structured questionnaire was used to collect the data. Independent sample $t$ test was performed to examine the differences on the choices of capital budgeting practices in terms of firms' characteristics. Outcome of the study revealed that the use of the payback method was preferred by small sized firms and mainly managed by financial officers with non- MBA educational qualifications and short tenure. Industry differences did not make any significant difference to the use of pay back period. Discounted payback period was more significantly used by small firms than large firms and managed by financial officers with non-MBA educational qualifications. Accounting rate of return was primarily applied by non-MBA financial officers and was also preferred by non-manufacturing firms. Net present value and internal rate of return were used mostly by large firms than small firms; these were mainly managed by financial officers who have qualified masters in business administration and long tenure. Sophisticated capital budgeting practices, in particular real option and game theory, were significantly preferred by large companies more than by small companies and those were managed by masters in business administration qualified financial officers who had a long tenure. Size of the capital budget increases the application of sophisticated and advanced capital budgeting practices. The relationship is much stronger in the case of sophisticated capital budgeting practices. A larger capital budget reduces the use of naive capital budgeting practices. Therefore, financial officers use sophisticated and advanced capital budgeting practices when the size of the capital budget is large. Overall, this study has 
made a parametric contribution. In a nutshell, this study serves as a springboard for future research.

\section{References}

Akalu,M.M. (2001). Re-examining project appraisal and control: developing a focus on wealth creation. International Journal of Project Management, 19, 375-383. https://doi.org/10.1016/S0263-7863(00)00019-3

Al-Ajmi,J.,Al-Saleh,N., \& Hussain,H.A. (2011). Investment appraisal practices: A comparative study of conventional and islamic financial institution. Advances in accounting, incorporating advances in international accounting, 27(2011), 111-124. https://doi.org/10.1016/j.adiac.2011.04.008

Andrés, P.de, Fuente, G.de.and Martín, P.S.(2015). Capital budgeting practices in Spain. BRQ Business Research Quarterly, 18(1), 37-56. https://doi.org/10.1016/j.brq.2014.08.002

Andor,G.Mohanty,S.K., \& Toth,T. (2011). Capital budgeting practices: A survey of Central and Eastern European firms. Available http://www.efmaefm.org/0EFMAMEETINGS/EFMA\%20ANNUAL\%20MEETINGS/2011Braga/papers/0118.pdf

Arnold, G.C., \& Hatzopoulos, P.D. (2000). The theory-practice gap in capital budgeting: evidence from the United Kingdom. Journal of Business Finance and Accounting, 10(5), 603-626. https://doi.org/10.1111/1468-5957.00327

Bennouna, K., Meredith, G.G., \& Marchant,T. (2010). Improved capital budgeting decision making: evidence from Canada. Management Decision 48(2), 225-247. https://doi.org/10.1108/00251741011022590

Billington, C., Johnson, B., \& Triantis, A.(2003). A real options perspective on supply chain management in high technology. Journal of Applied Corporate Finance, 15(2), 32-43. https://doi.org/10.1111/j.1745-6622.2002.tb00693.x

Bowman, E.H., \& Moskowitz, G.T.(2001). Real options analysis and strategic decision making. Organizations Science, 12(6), 772-777. https://doi.org/10.1287/orsc.12.6.772.10080

Brounen, D., de Jong, \& A.,Koedijk, K. (2004). Corporate finance in Europe: Confronting theory with practice. Financial Management, 33(4), 71-101. https://doi.org/10.2139/ssrn.559415

Cescon,F.(1998). Investment appraisal and measures of performance in Italian divisionalised companies. Journal of Management and Governance, 2(2), 191-212. https://doi.org/10.1023/A:1009946929486

Chen, S. (2008). DCF techniques and nonfinancial measures in capital budgeting: A contingency approach analysis. Behavioral Research in Accounting, 20(1), 13-29. https://doi.org/10.1023/A:1009946929486 
Cho,D.(1996). An alternative and practical theory of capital budgeting: Stockholder wealth maximization approach. The Mid - Atlantic Journal of Business,32, 93-104

Cooper, W.D., Morgan, R.G., Redman ,A., \& Smith,M.(2002). Capital budgeting models: theory vs. practice. Business Forum, 26(1\& 2), 15-19.

Copeland, T.E.,\& Weston, J.F.(1992). Financial theory and corporate policy, 3rd edn. Reading: Addison-Wesley Publishing Company Inc.

Dayananda, D., Irons, R., Harrison, S., Herbohn, J., \& Rowland, P. (2002). Capital budgeting: financial appraisal of investment projects. Edinburgh: Cambridge University Press. https://doi.org/10.1017/CBO9780511753701

Dedi,L., \& Orsag,S. (2007). Capital budgeting practices: A survey of Croatian firms. South East European Journal of Economics and Business, 2(1), 59-67. https://doi.org/10.2478/v10033-007-0016-y

Dragota,V., Tatu,L., Pele, D., Vintila, N., \& Semenescu,A.(2010). Capital budgeting: The Romanian university professors' points of view. The Review of Finance and Banking, 2(2),95-102.

Elumilade,D.O., Asaolu,T.O., \& Ologunde, A.O. (2006). Capital budgeting and economic development in the third world: The case of Nigeria. International Research Journal of Finance and Economics, 2(2), 136-152.

Farragher, E.J., Kleiman, R.T.,\& Sahu, A.P.(2001). The association between the use of sophisticated capital budgeting practices and corporate performance. The Engineering Economist, 46(4), 300-311. https://doi.org/10.1080/00137910108967579

Gliner,J.A., \& Morgan, G.A. (2000). Research methods in applied settings: an integrated approach to design \& analysis.Morwah, NJ: Lawrence Erlbaum

Graham, J., \& Harvey, C.(2001). The theory and practice of corporate finance: evidence from the field. Journal of Financial Economics, 60(2/3), 187-243. https://doi.org/10.1016/S0304-405X(01)00044-7

Haddad, K., Sterk, W., \& Wu, A. (2010). Capital budgeting practices of Taiwanese firms. Journal of International Management Studies, 5(1), 178-182.

Haka, S.F. (1987). Capital budgeting techniques and firm specific contingencies: A correlational analysis. Accounting, Organizations and Society, 12(1), 31-48. https://doi.org/10.1016/0361-3682(87)90014-6

Haka,S.F., Gordon,L.A., \& Pinches,G.E.(1985). Sophisticated capital budgeting selection techniques and firm performance. The Accounting Review, $L X$ (4), 651-668. https://doi.org/10.1007/978-1-4899-7138-8_24

Hermes, N., Smid, P., \& Yao,L. (2007). Capital budgeting practices: A comparative study of the Netherlands and China. International Business Review, 16(5), 630-654. https://doi.org/10.1016/j.ibusrev.2007.05.002 
Ho, S.S.M., \& Pike,R.H.(1992). Adoption of probabilistic risk analysis in capital budgeting and corporate Investment. Journal of Business Finance \& Accounting, 19(3), 387-405. https://doi.org/10.1111/j.1468-5957.1992.tb00631.x

Ho,S.S.M., \& Pike,R.H.(1998). Organizational characteristics influencing the use of risk analysis in strategic capital investment. The Engineering Economist, 43(3), 247-268. https://doi.org/10.1080/00137919808903198

Kersyte, A. (2011). Capital budgeting process: theoretical aspects. Economics and Management, 16(1), 1130-1134.

Kester, G.,Chang,R.P., $\quad$ Echanis, E.S., Haikal, S., Md.Isa, M ., Skully, M.T., Tsui,K.C.,\& Wang, C.J.(1999). Capital budgeting practices in the Asia-Pacific region: Australia, Hong Kong, Indonesia, Malaysia, Philippines, and Singapore. Financial Practice and Education 9(1), 25-33.

Kester,G., \& Robbins,G. (2011).The capital budgeting practices of listed Irish companies insights from financial officers on their investment appraisal techniques. Accountancy Ireland, 43(1), 28-30.

Kitili, E., \& Nganda, J. (2014).A survey of capital budgeting techniques applied by sugar companies in Western Kenya. Asian Journal of Education and e-Learning, 2(2), 140-145.

Khamees, B. A., Al-Fayoumi, N., \& Al-Thuneibat, A. A. (2010). Capital budgeting practices in the Jordanian industrial corporations, International Journal of Commerce and Management, 20(1), 49-63. https://doi.org/10.1108/10569211011025952

Lam,K.C., Wang,D., \& Lam,M.C.K.(2007).The capital budgeting evaluation practices (2004) of building contractors in Hong Kong. International Journal of Project Management, 25(8), 824-834. https://doi.org/10.1016/j.ijproman.2007.03.010

Lazaridis, I.T. (2004). Capital Budgeting Practices: A Survey in the Firms in Cyprus. Journal of Small Business Management, 42(4), https://doi.org/10.1111/j.1540-627X.2004.00121.x

Leon,F.M., Isa, M., \& Kester,G.W. (2008). Capital Budgeting Practices of Listed Indonesian Companies. Asian Journal of Business and Accounting, 1(2), 175-192.

Lord, B.R., Shanahan, Y.P., \& Boyd, J.R.(2004).. Capital Budgeting in New Zealand Local Authorities: An Examination of Practice. Accepted for Presentation at the Fourth Asia Pacific Interdisciplinary Research in Accounting Conference, (4 to 6 July 2004 Singapore), $1-18$

Mao,J.C.T.(1970). Survey of capital budgeting: theory and practice. Journal of finance, 25(2), 349-360. https://doi.org/10.1111/j.1540-6261.1970.tb00513.x

Maroyi,V., \& Poll,H.M. (2012). A survey of capital budgeting techniques used by listed mining companies in South Africa. African Journal of Business Management, 6(32), 9279-9292. https://doi.org/10.5897/AJBM12.747 
McGrath, R.G., \& Nerkar, A. (2004). Real options reasoning and a new look at the R\&D investment strategies of pharmaceutical firms. Strategic Management Journal, 25, 1-21. https://doi.org/10.1002/smj.358

Mohammed,M. (2013). The capital investment appraisal process- the case of Libya. unpublished $\mathrm{PhD}$ thesis.

Mustapha, M.Z., \& Mooi, S.T.L.(2001). Firm Performance and Degree of Sophistication of Capital Budgeting Practice: Some Malaysian Evidence. Proceedings of the Asia Pacific Management Conference, 279-290.

Mutairi, M. Al., Tian, G., Hasan, H., \& Tan, A.(2012). Corporate governance and corporate finance practices in a Kuwait Stock Exchange market listed firm: a survey to confront theory with practice. Corporate Governance: The International Journal of Business in Society,12(5), 595-615. https://doi.org/10.1108/14720701211275523

Payne, J. D., Heath, W. C., \& Gale, L. R.(1999). Comparative financial practice in the US and Canada: Capital budgeting and risk assessment techniques. Financial Practice and Education, 9(1), 16-24.

Pereiro, L. E.(2006). The practice of investment valuation in emerging markets: Evidence from Argentina. Journal of Multinational Financial Management, 16(2),160-183. https://doi.org/10.1016/j.mulfin.2005.06.001

Peterson, P.P. \& Fabozzi, F.J.(2002). Capital Budgeting: Theory and Practice, Wiley \& Sons, New York, NY.

Pike,R.(1996). A longitudinal survey on capital budgeting practices. Journal of Business financing and Accounting, 23(1), 79-92. https://doi.org/10.1111/j.1468-5957.1996.tb00403.x

Poudel,K.L., Sugimoto,Y., Yamamoto, N., Nishiwaki,A., \& Kano,H.(2010). Capital Budgeting Analysis of Organic Coffee Production in Gulmi District of Nepal. International Research Journal of Finance and Economics, 43,123-132.

Rogers, E.M. (1995). Diffusion of Innovations. 4th edn., New York: Free Press.

Ryan, P. A., \& Ryan, G. P. (2002). Capital budgeting practices of the fortune 1000: how have things changed?. Journal of business and Management, 8(4), 355-364.

Sandahl , G., \& Sjogren, S. (2003). Capital budgeting methods among Sweden's largest groups of companies. The state of the art and a comparison with earlier studies. International Journal of Production Economics, 84(1), 51-69. https://doi.org/10.1016/S0925-5273(02)00379-1

Sekwat, A.(1999). Capital budgeting practices among Tennessee Municipal Government. Government Finance Review(June),15-19.

Shinoda,T.( 2010). Capital Budgeting Management Practices in Japan- A Focus on the Use of Capital Budgeting Methods. Economic Journal of Hokkaido University, 39 (2010),39 - 50. 
Singh,S., Jain,P.K., \& Yadav,S.S.(2012). Capital budgeting decisions: evidence from India. Journal of Advances in Management Research, 9(1), 96-112. https://doi.org/10.1108/09727981211225671

Trigeorgis, L.(1993). Real options and interactions with financial flexibility. Financial Management, 22(3), 202-224. https://doi.org/10.2307/3665939

Truong, G., Partington,G., \& Peat,M.(2008). Cost of capital estimation and capital budgeting practice in Australia. Australian Journal of Management, 33(1), 95-121. https://doi.org/10.1177/031289620803300106

Tufuor,A.N.K., \& Doku,J.N.(2013). Capital budgeting practices of emerging market economies: evidence from listed Ghanain firms. Research Journal of Finance and Accounting, 4(17), 26-35.

Verbeeten, F.H.M.(2006). Do organizations adopt sophisticated capital budgeting practices to deal with uncertainty in the investment decision? A research note. Management Accounting Research, 17(1), 106-120. https://doi.org/10.1016/j.mar.2005.07.002

Verma, S., Gupta,S., \& Batra,R.(2009). A survey of capital budgeting practices in corporate India. The Journal of Business Perspective, 13(3), 1-17. https://doi.org/10.1177/097226290901300301

Williams, J.J., \& Seaman, A.E.(2001).Predicting change in management accounting systems: national culture and industry effects. Accounting, Organizations and Society, 26(4), 443-460. https://doi.org/10.1016/S0361-3682(01)00002-2

Wnuk-Pel, T.(2014).Capital budgeting practices in non-manufacturing companies in Poland. Social Sciences, 82(4), 59-69. https://doi.org/10.5755/j01.ss.82.4.6612

Wolffsen, P. (2012). Modification of capital budgeting under uncertainty. Taikomoji ekonomika: $\quad$ sisteminiai $\quad$ tyrimai, $\quad(6 / 2), \quad 143-159$. https://doi.org/10.7220/AESR.1822.7996.2012.6.2.9

Wong, K.A., Farragher, E. J., \& Leung, R. K. C.(1987).Capital investment practices: A survey of large corporations in Malaysia, Singapore and Hong Kong. Asia-Pacific Journal of Management, 4(2), 112-123. https://doi.org/10.1007/BF01732852

Zubairi,H.J.(2008).Capital budgeting decision making practices in Pakistan. https://doi.org/10.2139/ssrn.1308662 